\title{
Techno-economic and environmental performances of heating systems for single-family code-compliant and passive houses
}

\author{
Ambrose Dodoo, ${ }^{1, *}$ \\ ${ }^{1}$ Department of Building Technology, Linnaeus University, Växjö, Sweden
}

\begin{abstract}
In this study the implications of different energy efficiency requirements and heating solutions for versions of a single-family house in southern Sweden is explored. Final energy use, primary energy use, climate impacts and lifecycle cost of heat supply are analyzed for the building versions designed to meet the current Swedish BBR 2015 building code and heated with district heating or exhaust air heat pump. A case where the building is designed to the Swedish passive house criteria and heated with exhaust air heat pump is also analyzed. The district heating is assumed to be supplied from combined heat and power plants using bio-based fuels. For the heat pump solutions, cases are analyzed where the electricity supply is from coalfired condensing power plant or fossil gas combined cycle power plant as baseline scenario, and from a combination of improved fossil power plants and non-fossil power plants as long-term scenario. The analysis considers the entire energy chain from natural resources to the final energy services. The results show that the BBR heat pump heated building use the most primary energy compared to the other two alternatives. Lifecycle cost is reduced by about $7-12 \%$ when district heating is used instead of heat pump for a BBR code-compliant building. This study shows the importance of lifecycle and system-wide perspectives in analyzing the resource efficiency and climate impacts as well as economic viabilities of heating solutions for houses.
\end{abstract}

\section{Introduction}

The building sector contributes largely to the total primary energy use and carbon dioxide $\left(\mathrm{CO}_{2}\right)$ emission in many countries, and a large part of this energy is used for space conditioning of buildings. Buildings account for $40 \%$ of the total energy use in the European Union, [1], and in Sweden the residential and service sectors account for $40 \%$ of the total final energy use [2]. The building sector therefore presents a significant opportunity to reduce primary energy use and $\mathrm{CO}_{2}$ emissions in the built environment.

The European Union's energy performance of buildings directive requires all member states to set and implement minimum energy efficiency standard for buildings [3]. The Swedish government's bill on energy efficiency and smart construction aims to reduce total energy use per heated building floor area by $20 \%$ by 2020 and $50 \%$ by 2050, using 1995 as reference [4]. Energy efficient buildings are suggested as key part of the overall strategy to break Sweden's dependence on fossil fuels to achieve a sustainable and a climate neutral society [4].

In Sweden, various strategies have been deployed to reduce energy use intensity of buildings. A Swedish criterion for passive house has been developed and some municipalities have established energy plans to promote low-energy buildings. The municipality of Växjö, in southern Sweden, aims to be climate neutral by 2030 [5], and has demanded when selling land to private developers that new residential buildings are connected to district heating networks [6]. Alternative heating solutions as electric-based heat pumps are only permitted when new buildings are constructed to energy efficiency level of passive house. However, the Swedish Competition Authority and some stakeholders claim that the municipality's requirement is contrary to national competition regulations [6].

The current Swedish building code (BBR 2015) [7] specifies mandatory energy performance requirements for buildings depending on their purpose, end-use heating systems and climate zones. It categorizes buildings as residential or non-residential and electric or non-electric heated for four defined climate zones. A building is categorized as electric heated if its installed power for heating is more than $10 \mathrm{~W} / \mathrm{m}^{2}$. The energy performance requirements for buildings are given as the specific energy use, comprising the purchased energy for space heating, tap water heating and electricity for fans and pumps but excluding electricity for household appliances and lighting. The BBR also requires that the average U-value for the whole building thermal envelope must not exceed $0.40 \mathrm{~W} / \mathrm{m}^{2} \mathrm{~K}$ for residential buildings.

The passive house criteria suggest a voluntary and a stricter purchased energy limits for buildings using similar principles as the BBR [8]. Table 1 shows the energy efficiency requirements of the current BBR and Swedish passive house criteria for single-family houses.

Corresponding author: ambrose.dodoo@1nu.se 
Table 1. Specific purchased energy use $\left(\mathrm{kWh} / \mathrm{m}^{2}\right)$ for singlefamily houses for the BBR and passive house criteria.

\begin{tabular}{llccc}
\hline Buildings & \multicolumn{4}{c}{ Climate zones } \\
\hline Electric heated: & I & II & III & IV \\
$\quad$ BBR & 95 & 75 & 55 & 50 \\
Passive house & 29 & 27 & 25 & 25 \\
Non-electric heated : & & & & \\
$\quad$ BBR & 130 & 110 & 90 & 80 \\
Passive house & 58 & 54 & 50 & 50 \\
\hline
\end{tabular}

The heat supply of a building can be provided by different types of end-use heating systems resulting in a large variation in primary energy use and $\mathrm{CO}_{2}$ emission for a given final energy use [9]. Primary energy largely determines natural resource use efficiency and the climate impact of energy services. It is important to consider primary energy use, rather than focusing solely on final or purchased energy, when analyzing the climate impact of energy supply of a building. A comprehensive approach considering the entire energy chain from natural resources to final energy services is needed to understand the system-wide implications of a building's heat supply and energy use [10].

In this study the system-wide primary energy use and climate impact of a Swedish single-family house designed to meet the energy efficiency requirement of the BBR [7] and heated with district heating or exhaust air heat pump are analyzed. A case where the singlefamily house is also designed to the Swedish passive house criteria [8] and heated with exhaust air heat pump is analyzed. The analysis considers the context of Växjö

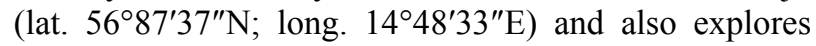
the lifecycle cost implications of the heating solutions for the analyzed building versions.

\section{Methods}

In this study, energy balance modelling, energy systems analysis and lifecycle cost calculations are integrated to explore the implications of energy requirements and heating solutions for versions of a case-study building.

\subsection{Case-study building}

The analysis is based on a real single-family house with wood structure. Figure 1 shows the front elevation while Figure 2 shows the ground floor plan of the house. To explore the implications of the different energy efficiency requirements, changes including improved thermal envelope and airtightness are modeled to the building to achieve buildings which meet the requirements for climate zone III for the BBR [7] or the passive house criteria [8]. The modeled buildings are assumed to be heated with district heat or exhaust air heat pump. Table 2 shows key architectural as well as construction details while Table 3 shows the thermal characteristics of the modeled building versions. In addition to lower $\mathrm{U}$-values and ventilation heat recovery (VHR) unit of $80 \%$ efficiency, the passive house is assumed to have much better airtightness than the BBR code-compliant buildings with the different heating solutions.

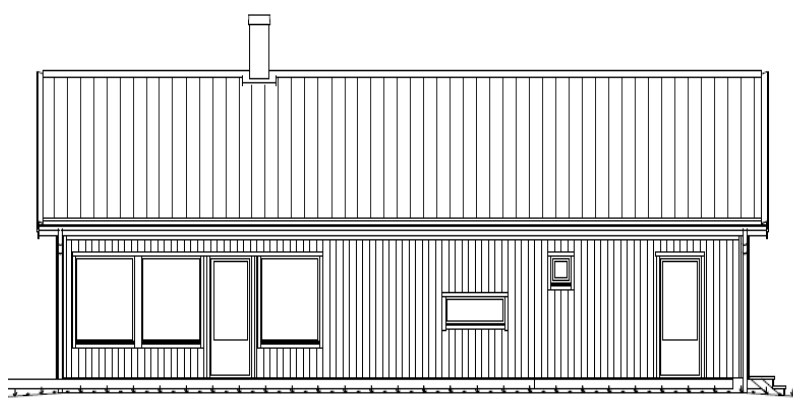

Fig. 1. Front façade of the studied building.

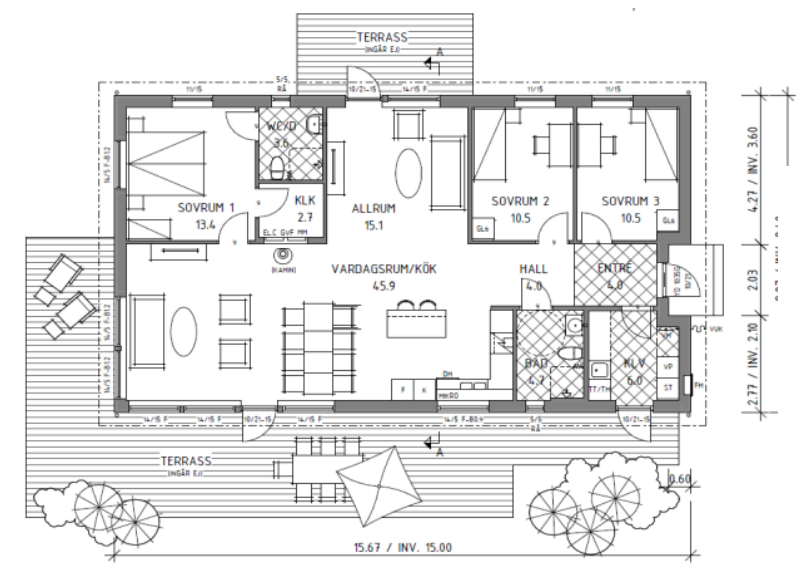

Fig. 2. Ground floor plan of the studied building.

Table 2. Key construction details of the case-study building.

\begin{tabular}{lc}
\hline Description & Values \\
\hline Building gross floor area & $142.0 \mathrm{~m}^{2}$ \\
Heated floor area & $124.4 \mathrm{~m}^{2}$ \\
Ventilated volume & $298.9 \mathrm{~m}^{3}$ \\
Exterior wall area (excl. openings) & $90.3 \mathrm{~m}^{2}$ \\
Window and door areas (S/W/N/E $)$ & $25 \mathrm{~m}^{2}(11.5 / 9.5 / 2.1 / 2.1)$ \\
Roof-ceiling area & $124.4 \mathrm{~m}^{2}$ \\
Sab on ground area & $124.4 \mathrm{~m}^{2}$ \\
\hline${ }^{\mathrm{a}} \mathrm{S} / \mathrm{W} / \mathrm{N} / \mathrm{E}$ denotes windows in South, West, North and East \\
orientations, respectively.
\end{tabular}

Table 3. Thermal properties of the modeled buildings.

\begin{tabular}{llll}
\hline Description & \multicolumn{3}{l}{ Values or description } \\
\cline { 2 - 4 } & $\begin{array}{l}\text { BBR } \\
\text { district } \\
\text { heated }\end{array}$ & $\begin{array}{l}\text { BBR heat } \\
\text { pump } \\
\text { heated }\end{array}$ & $\begin{array}{l}\text { Passive } \\
\text { heat pump } \\
\text { heated }\end{array}$ \\
\hline U-values $\left(\mathrm{W} / \mathrm{m}^{2} \mathrm{~K}\right)$ : & & & \\
$\quad$ Ground floor & 0.11 & 0.11 & 0.11 \\
Exterior walls & 0.15 & 0.19 & 0.14 \\
Windows & 1.00 & 1.40 & 1.00 \\
Doors & 1.00 & 1.00 & 1.00 \\
Roof & 0.09 & 0.10 & 0.09 \\
Average & 0.17 & 0.21 & 0.17 \\
Infiltration $\left(1 / \mathrm{s} \mathrm{m}^{2} @ 50 \mathrm{~Pa}\right)$ & 0.55 & 0.80 & 0.40 \\
Mechanical ventilation & Exhaust & Exhaust & Balanced $^{\mathrm{a}}$ \\
\hline
\end{tabular}

${ }^{\mathrm{a}}$ with VHR 


\subsection{Final and purchased energy simulations}

The annual specific final and purchased energy demands for the building versions are calculated hour-by-hour using VIP-Energy [11], which is a multi-zone dynamic energy balance calculation software. It allows detailed modelling of heat storage capacity and thermal bridges in one-, two- and three-dimensional building envelope components. The software is increasingly used in Sweden by consultants, construction companies and researchers. Validation of VIP-Energy in the International Energy Agency's BESTEST suggests that the software has reliable algorithms and models [11].

Climate data representative of Växjö for recent years (1996-2005) is used for the simulations. Table 4 shows key average values for Växjö's climate during this period. Data and assumptions for the simulations are mainly based on SVEBY [12] and Dodoo et al. [13]. Table 5 list some key data used for the simulations.

Table 4. Key climate data for the energy balance analysis.

\begin{tabular}{lc}
\hline Description & Values \\
\hline Average annual ambient temperature, ${ }^{\circ} \mathrm{C}$ & 7 \\
Maximum annual ambient temperature, ${ }^{\circ} \mathrm{C}$ & 28 \\
Minimum annual ambient temperature, ${ }^{\circ} \mathrm{C}$ & -17 \\
Average horizontal solar radiation, $\mathrm{W} / \mathrm{m}^{2}$ & 105 \\
Average annual relative humidity, $\%$ & 81 \\
Average annual wind speed, $\mathrm{m} / \mathrm{s}$ & 3 \\
Air pressure outside, $\mathrm{hPa}$ & 1000 \\
\hline
\end{tabular}

Table 5. Major values and assumptions for the energy balance simulations.

\begin{tabular}{lll}
\hline Parameter & Data & Remark/Source \\
\hline Heating set-point & $21^{\circ} \mathrm{C}$ & SVEBY [12] \\
Ventilation rate & $0.351 / \mathrm{m}^{2} \mathrm{~s}$ & BBR [7] \\
Heat gains: & & \\
Persons & $1.00 \mathrm{~W} / \mathrm{m}^{2}$ & VIP-Energy [11] \\
Process & $0.70 \mathrm{~W} / \mathrm{m}^{2}$ & VIP-Energy [11] \\
Sun & Calculated & Calculated hourly \\
Hot water & $2.85 \mathrm{~W} / \mathrm{m}^{2}$ & Based on standard taps \\
Fan efficiency & $50 \%$ & Dodoo et al. [13] \\
Electric power use & $2.74 \mathrm{~W} / \mathrm{m}^{2}$ & Based on standard appliances \\
\hline
\end{tabular}

\subsection{Primary energy and $\mathrm{CO}_{2}$ emission analyses}

Based on the final and purchased energy use, the operation primary energy use and fossil $\mathrm{CO}_{2}$ emissions of the building versions are calculated using the ENSYST software [14]. This software estimates primary energy use and fossil $\mathrm{CO}_{2}$ emissions taking into account the entire energy chain from natural resources extraction to supply of final energy. This study follows assumptions in [9] about the production and transport of fuels for electricity and heat when using the ENSYST software.

For the district heated building version, the heat is assumed to be produced from combined heat and power (CHP) plant and boilers using $100 \%$ biomass fuels as in the city of Växjö. The relationship between heat and electricity capacity for the CHP is assumed to be the same as for Växjö Energy AB's (VEAB) CHP plant Sandvik 3. The total heat and electricity efficiency of the CHP is suggested to be $87 \%$, and with flue gas condensing the total efficiency for only heat production becomes $107 \%$ [15]. The distribution loss in the district heating network is assumed to be 7\% [16] and the loss in the heat exchanger in the building is assumed to be $5 \%$ [17]. To address the allocation issue associated with coproduction of electricity with the district heat, the subtraction method of allocation is used [10]. Based on this, the cogenerated electricity is assumed to replace electricity from a stand-alone reference coal-fired or fossil-gas fired condensing power plant. The biomassbased boiler for district heat production is suggested to have conversion efficiency of $86 \%$ [15].

For the heat pump heated building versions, the exhaust air heat pump is assumed to have a coefficient of performance (COP) of 2.63, based on [11], with an auxiliary electric heaters of $100 \%$ efficiency. The Swedish power system is linked to the Nordpool market for electricity trading where the marginal electricity is typically suggested to be coal-based, and may change to fossil gas in the future [18]. In this study cases are analyzed where the electricity supply is from stand-alone coal-fired condensing power plant or stand-alone fossil gas combined cycle power plant as baseline scenario, and from a combination of improved fossil power plants, and non-fossil power plants as plausible long-term scenario. In the baseline scenario, the coal-fired condensing power and the fossil gas combined cycle power plants are assumed to have conversion efficiencies of $35 \%$ and $44 \%$, respectively, based on current typical performance of these power plants [19]. In the long term, the existing power plants may be renewed after their technical or economic lifetimes with state-of-the-art technologies. Further, the deployment and utilization of non-fossil electricity sources is suggested to be strengthened, to achieve national and international energy and climate targets. In the long-term scenario, non-fossil electricity sources comprising nuclear power, bio-electricity and wind/solar power are each assumed to cover a month's electricity demand for the buildings during the summer period, from June to August, corresponding to 3 months in all. The conversion efficiencies for the bio-electricity and the nuclear power are assumed to be $40 \%$ and $36 \%$, respectively. For the wind/solar power, only the harvested electricity is taken into account. The remaining electricity (corresponding to 9 months) is assumed to be covered by an improved reference stand-alone coalbased power plant with $40 \%$ conversion efficiency or an improved reference stand-alone fossil gas-based power plant with $50 \%$ conversion efficiency. State-of-the-art plants with efficiencies around these values are reported in literature [e.g. 20]. In both the baseline and long-term scenarios, distribution loss for electricity is assumed to be $7 \%[16]$.

The above power plants are considered to cover the base-load, assumed to be $95 \%$ of electricity production, with light-oil-fired gas turbines of $34 \%$ efficiency covering the remaining $5 \%$ as peak production. 
In the long term, the existing biomass-based boiler for district heat production is assumed to be renewed with an improved type of $107 \%$ conversion efficiency.

A key methodological issue is to objectively account for the implications of the differences in biomass needs of the systems as the district heating solution is based on bioenergy while the heat pumps are based on fossil energy. In this study, two approaches are used to model this issue. In the first approach a simplified means is used and the implication of the biomass use differences of the district heating and the heat pump solution are not modelled. In the second approach, an equal amount of biomass is assumed to be available for use in the systems of the different solutions. Hence the same amount of biomass used for the BBR district heated building is allocated to the heat pump heated buildings. This spare biomass is credited to the heat pump system, assuming it is used to produce bio-electricity to replace the reference power from fossil-based stand-alone production.

\subsection{Economic analysis}

Lifecycle cost method is used to evaluate the economic implications of the heating solution for the building versions. The analysis considered the initial investment costs of the heating solutions, the net present value of operation energy and maintenance costs, and the present worth of the future sum for reinvestment and residual values. The investment cost for heat supply from district heating is based on data from Vattenfall [21] while that for the exhaust heat pump is from NIBE [22]. The district heating investment cost includes substations, and installation, excavation and piping costs. The cost for the heat pump includes the cost of installation and equipment which comes with an auxiliary electric heater. The technical lifetimes for the district heating sub-station and heat pump are assumed to be 25 and 15 years, respectively, based on data from the Danish Energy Agency [23]. The operation energy costs are calculated with district heat and electricity prices applicable for Växjö in 2018 [24]. The NPV of operation and maintenance costs for the heating solutions are calculated for two cases to account for uncertainties and variabilities in key economic data: (i) one with discount rate of $5 \%$ and annual energy price increase of $1 \%$ reflecting the current situation generally; and (ii) another with real discount rate of $1 \%$ and annual energy price increase of $3 \%$, which is noted as expedient to encourage energy related sustainability investments [24]. The lifecycle cost is calculated for 25 years and the heat pump will need to be replaced once during this period. The residual value of the renewed heat pump after this period is estimated assuming linear depreciation.

\section{Results}

\subsection{Specific final and purchased energy}

Table 6 shows the annual final energy and purchased energy use for the buildings including space and tap water heating and ventilation electricity. The passive heat pump heated building has the lowest final and purchased energy demands. The BBR heat pump heated building has greater final energy and lower purchased energy use compared to the district heated alternative. The BBR district heated building has $61-74 \%$ more purchased energy than the heat pump heated buildings.

Table 6. Annual specific final and purchased energy for space and tap water heating and for ventilation electricity.

\begin{tabular}{|c|c|c|c|}
\hline \multirow[t]{2}{*}{ Description } & \multicolumn{3}{|c|}{ Final or purchased energy $\left(\mathrm{kWh} / \mathrm{m}^{2}\right)$} \\
\hline & $\begin{array}{l}\text { BBR } \\
\text { district } \\
\text { heated }\end{array}$ & $\begin{array}{l}\text { BBR heat } \\
\text { pump } \\
\text { heated }\end{array}$ & $\begin{array}{l}\text { Passive } \\
\text { heat pump } \\
\text { heated }\end{array}$ \\
\hline \multicolumn{4}{|l|}{ Final energy demand: } \\
\hline Space heating & 58 & 71 & 29 \\
\hline Ventilation electricity & 2 & 2 & 5 \\
\hline Tap water heating & 25 & 25 & 25 \\
\hline Total & 85 & 98 & 59 \\
\hline Purchased energy use & 85 & 33 & 22 \\
\hline
\end{tabular}

\subsection{Primary energy use and $\mathrm{CO}_{2}$ emissions}

\subsubsection{Baseline scenario}

Table 7 shows the annual primary energy use of the buildings and corresponding $\mathrm{CO}_{2}$ emissions are shown in Table 8. The carbon benefits from spare biomass is also shown for the heat pump heated buildings and denotes the emissions avoided when the same quantity of biomass in the district heating system is assumed to be used to produce bio-based electricity, replacing the reference electricity. The BBR district heated building gives the lowest primary energy use when the reference power is based on coal while the passive heat pump heated building gives the lowest primary energy use when the reference power is based on fossil gas. The annual fossil $\mathrm{CO}_{2}$ emissions show that the BBR district heated building gives the lowest net $\mathrm{CO}_{2}$ emission for all cases, irrespective of the reference power plant.

Table 7. Annual primary energy use of the buildings when the reference electricity is from coal or fossil gas plant.

\begin{tabular}{lllll}
\hline \multirow{2}{*}{ Description } & \multicolumn{5}{l}{ Primary energy $\left(\mathrm{kWh} / \mathrm{m}^{2}\right)$} \\
\cline { 2 - 5 } & $\begin{array}{l}\text { Space } \\
\text { heating }\end{array}$ & $\begin{array}{l}\text { Ventilation } \\
\text { electricity }\end{array}$ & $\begin{array}{l}\text { Tap water } \\
\text { heating }\end{array}$ & Total \\
\hline $\begin{array}{l}\text { Coal power plant: } \\
\text { BBR district heated }\end{array}$ & 33 & 7 & 14 & $\mathbf{5 4}$ \\
$\begin{array}{l}\text { BBR heat pump } \\
\text { heated }\end{array}$ & 77 & 7 & 27 & $\mathbf{1 1 1}$ \\
$\begin{array}{l}\text { Passive heat pump } \\
\text { heated }\end{array}$ & 31 & 17 & 26 & $\mathbf{7 4}$ \\
$\begin{array}{l}\text { Fossil gas power plant: } \\
\text { BBR district heated }\end{array}$ & 49 & 5 & 21 & $\mathbf{7 5}$ \\
$\begin{array}{l}\text { BBR heat pump } \\
\text { heated }\end{array}$ & 63 & 5 & 22 & $\mathbf{9 0}$ \\
$\begin{array}{l}\text { Passive heat pump } \\
\text { heated }\end{array}$ & 25 & 14 & 22 & $\mathbf{6 1}$ \\
\hline
\end{tabular}


Table 8. Annual fossil $\mathrm{CO}_{2}$ emission of the buildings when the reference electricity is from coal or fossil gas plant.

\begin{tabular}{|c|c|c|c|c|c|}
\hline \multirow[b]{2}{*}{ Description } & \multicolumn{4}{|c|}{ Fossil $\mathrm{CO}_{2}$ emission $\left(\mathrm{kgCO}_{2} / \mathrm{m}^{2}\right)$} & \multirow[b]{2}{*}{ Total } \\
\hline & $\begin{array}{l}\text { Space } \\
\text { heating }\end{array}$ & $\begin{array}{l}\text { Venti- } \\
\text { tion } \\
\text { elec- } \\
\text { tricity }\end{array}$ & $\begin{array}{l}\text { Tap } \\
\text { water } \\
\text { heating }\end{array}$ & $\begin{array}{l}\text { Spare } \\
\text { biomass }\end{array}$ & \\
\hline \multicolumn{6}{|l|}{ Coal power plant: } \\
\hline BBR district heated & -21 & 2 & -9 & - & -28 \\
\hline $\begin{array}{l}\text { BBR heat pump } \\
\text { heated }\end{array}$ & 22 & 2 & 8 & -42 & -10 \\
\hline $\begin{array}{l}\text { Passive heat pump } \\
\text { heated }\end{array}$ & 9 & 5 & 8 & -42 & -20 \\
\hline \multicolumn{6}{|l|}{ Fossil gas power plant: } \\
\hline BBR district heated & -12 & 1 & -5 & - & -16 \\
\hline $\begin{array}{l}\text { BBR heat pump } \\
\text { heated }\end{array}$ & 13 & 1 & 5 & -24 & -5 \\
\hline $\begin{array}{l}\text { Passive heat pump } \\
\text { heated }\end{array}$ & 5 & 3 & 5 & -24 & -11 \\
\hline
\end{tabular}

The primary energy use for a 25 year period for the building versions are shown in Figure 3 for the various energy end-use services when using coal-based electricity. The primary energy for space heating for the BBR heat pump heated building is about a factor of 2.4 and 2.5 greater than for the BBR district heated and passive heat pump heated buildings, respectively.

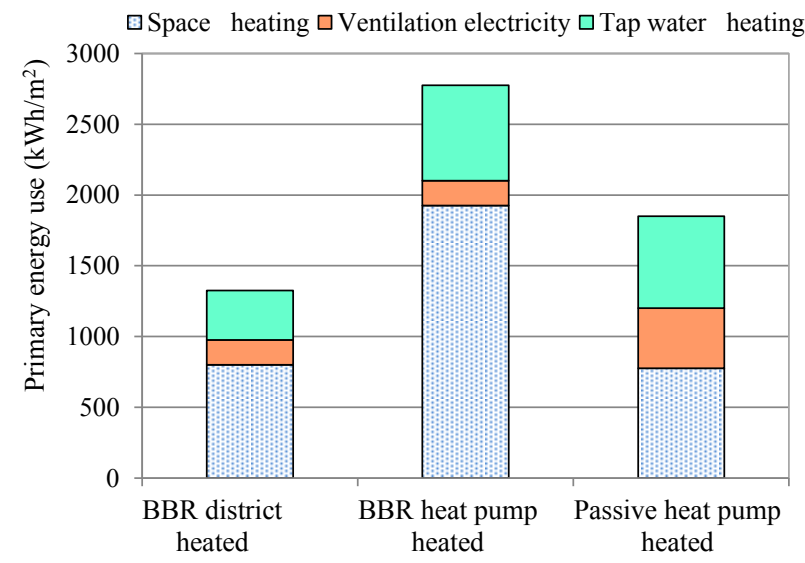

Fig. 3. Primary energy use for different energy end-use services for the buildings for a 25 year period when the reference power is from coal-fired plant.

Figure 4 shows the building's total primary energy use for a 25-year period when the reference electricity is from coal-based or fossil gas-based power plant. The primary energy use for the heat pump heated buildings is reduced between 18 and $19 \%$ when the reference electricity is from fossil gas-based instead of coal-based power plant. In contrast, the primary energy use of the district heated building is increased by $40 \%$ when the reference electricity is from fossil gas-based instead of coal-based power plant. The electricity cogenerated with the district heat replaces that which otherwise would have been produced in a higher-efficiency stand-alone power plant when the reference electricity is from fossil gas-based instead of coal-based power plant.

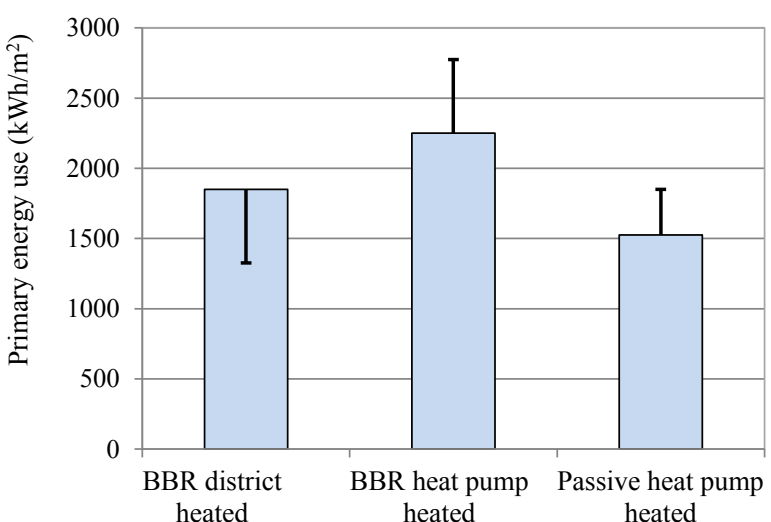

Fig. 4. Total primary energy use of the building versions for a 25 year period. The main bars show when the reference power is based on fossil gas-fired plant and the error bars show when it is based on coal-fired plant.

Figures 5 and 6 show the buildings' fossil $\mathrm{CO}_{2}$ emissions for 25 years period for the cases where the differences in biomass use of the heating solutions is not accounted and where that is accounted, respectively. The approaches give the same ranking for the heating solutions. However negative $\mathrm{CO}_{2}$ emissions, denoting avoided emissions, is achieved also for the heat pump solutions when the implication of spare biomass is accounted.

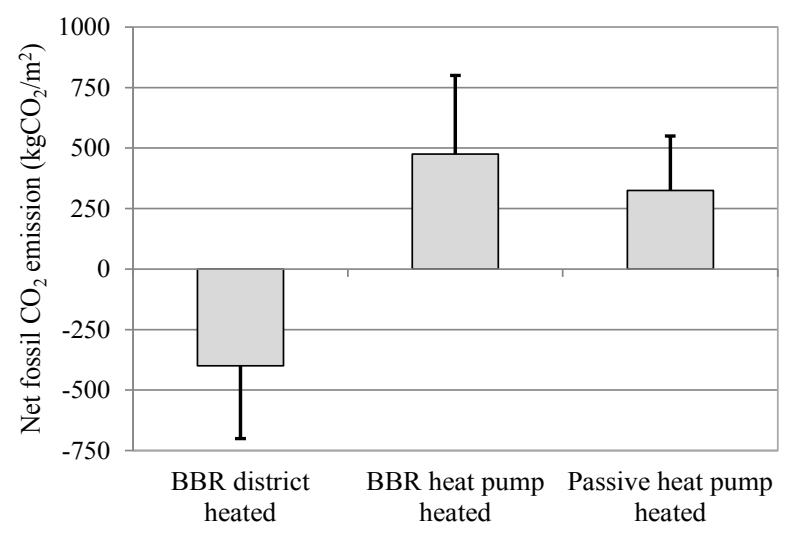

Fig. 5. Net fossil $\mathrm{CO}_{2}$ emission for a 25 -year period when the implication of spare biomass is not accounted. The main bars show when the reference power is based on fossil gas-fired plant and the error bars show when it is coal-fired plant.

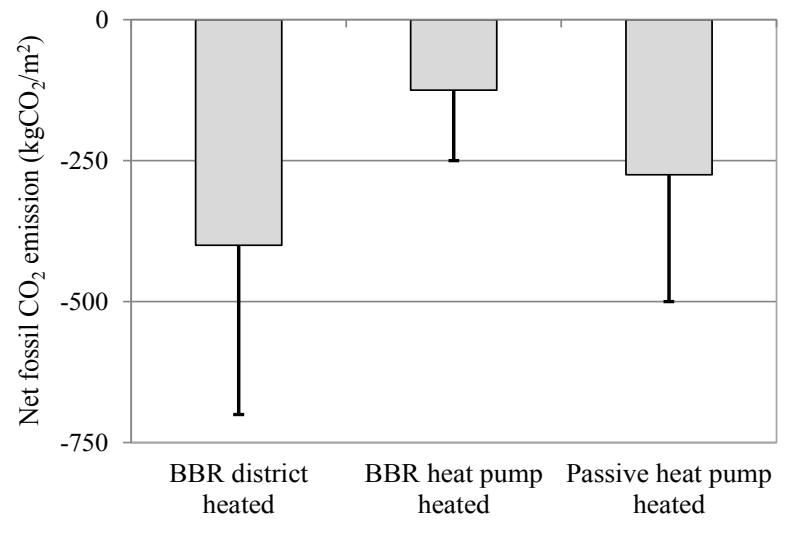

Fig. 6. Net fossil $\mathrm{CO}_{2}$ emission (avoided) for the 25 year when the implication of spare biomass is accounted. The main bars show when the reference power is based on fossil gas-fired plant and the error bars show when it is coal-fired plant. 


\subsubsection{Long-term scenario}

Figure 7 shows the primary energy use of the building versions for a 25 -year period when energy supply is based on the plausible long term scenario. Compared to the baseline scenario, primary energy use for the heat pump heated buildings is reduced while that for the district heated building is increased. The differences in primary energy use between the BBR district heated and heat pump heated buildings is very minor when the reference electricity is from fossil gas-fired power plant. The primary energy for the BBR district heated and passive heat pump heated buildings are similar for the coal-based reference power plant. The rankings of the solutions are similar to that of the baseline scenario.

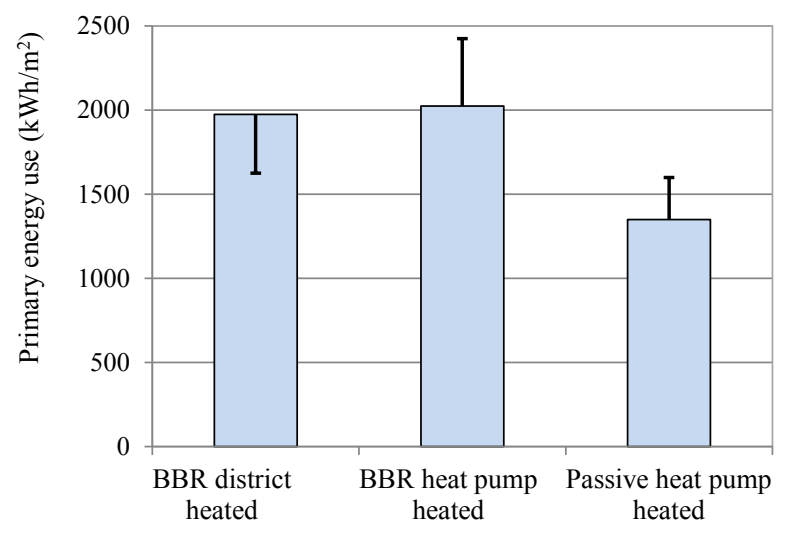

Fig. 7. Total primary energy use of the buildings for a 25 year period when using improved energy supply systems. The main bars show when reference power is based on fossil gas-fired plant and the error bars show when it is coal-fired plant.

The ranking of the climate impacts of the heating solutions for the buildings differ for the long-term and the baseline scenarios, as shown in Figure 8 (with carbon benefits of spare biomass considered). When using the improved fossil and the non-fossil power plants, the passive heat pump heated building now gives the lowest $\mathrm{CO}_{2}$ emissions, followed by the BBR district heated building. Still, the BBR heat pump heated building gives the most $\mathrm{CO}_{2}$ emissions among the building versions.

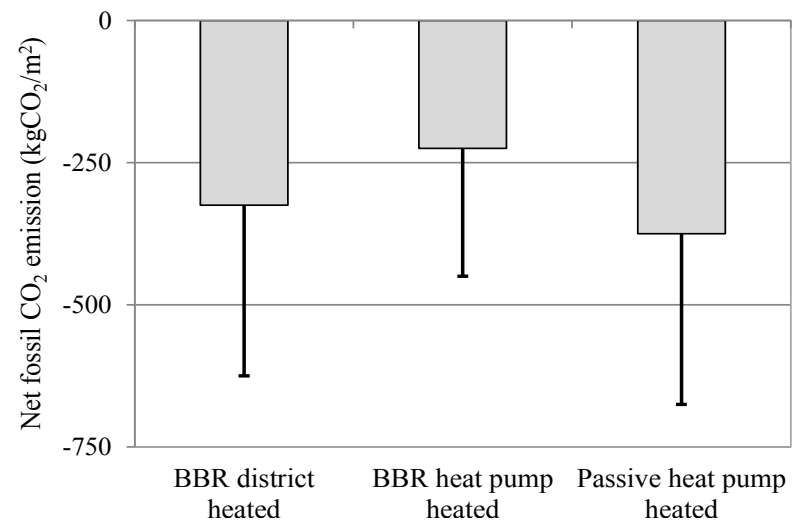

Fig. 8. Net fossil $\mathrm{CO}_{2}$ emission (avoided) for the 25 year period when using improved energy supply systems and when the implication of spare biomass is accounted. The main bars show when reference power plant is based on fossil gas-fired plant and the error bars show when it is coal-fired plant.

\subsection{Economic implications}

The economic implications of the different heating solutions for the building versions are summarized in Tables 9 and 10, which show lifecycle costs for 25 years and for different sets of real discount rates and annual energy price increases. The calculations show that the lifecycle cost of the options is sensitive to the real discount rate and energy price increase over time. Still, this does not change the ranking of the analyzed solutions from economic perspective. Overall the lifecycle cost is lowest for the heat pump solution with passive house level of energy efficiency, followed by the district heating solution with BBR level of energy efficiency. The lifecycle cost is highest for the heat pump solution with BBR level of energy efficiency. Lifecycle cost is reduced by about $7-12 \%$ when district heating is used instead of heat pump for the BBR codecompliant building.

Table 9. Costs implications of heating solutions with real discount rate of $5 \%$ and $1 \%$ annual energy price increase.

\begin{tabular}{llll}
\hline Heating solution related & $\begin{array}{l}\text { BBR } \\
\text { parameters: }\end{array}$ & $\begin{array}{l}\text { BBR heat } \\
\text { heated }\end{array}$ & $\begin{array}{l}\text { Passive } \\
\text { heated } \\
\text { heat pump } \\
\text { heated }\end{array}$ \\
\hline Initial investment cost $(€)$ & 8500 & 10437 & 10437 \\
Operation \& maintenance costs & 13296 & 10640 & 7093 \\
Re-investment (future) cost $(€)$ & - & 4781 & 4781 \\
Residual value $(€)$ & - & -1027 & -1027 \\
\hline Lifecycle cost for 25 years $(€)$ & 21796 & 24831 & 17530 \\
\hline Specific yearly cost $\left(€ / m^{2}\right.$ year $)$ & 7.01 & 7.98 & 5.64 \\
\hline
\end{tabular}

Table 10. Costs implications of heating solutions with real discount rate of $1 \%$ and $3 \%$ annual energy price increase.

\begin{tabular}{llll}
\hline $\begin{array}{l}\text { Heating solution related } \\
\text { parameters: }\end{array}$ & $\begin{array}{l}\text { BBR } \\
\text { district } \\
\text { heated }\end{array}$ & $\begin{array}{l}\text { BBR heated } \\
\text { heat }\end{array}$ & $\begin{array}{l}\text { Passive } \\
\text { heat pump } \\
\text { heated }\end{array}$ \\
\hline Investment cost $(€)$ & 8500 & 10437 & 10437 \\
Operation \& maintenance costs & 27078 & 21669 & 14445 \\
Reinvestment cost $(€)$ & - & 8901 & 8901 \\
Residual value $(€)$ & - & -2713 & -2713 \\
\hline Lifecycle cost for 25 years $(\epsilon)$ & 35578 & 38294 & 24882 \\
\hline Specific annual cost $\left(\epsilon^{2} m^{2}\right.$ year) & 11.44 & 12.31 & 8.00 \\
\hline
\end{tabular}

\section{Discussion and conclusions}

A key goal of this techno-economic and environmental assessment is to understand the relative performance of alternative heating solutions for single-family residential buildings in a Swedish context. The analysis presented here explored cases where a single-family building is designed to meet the current Swedish building code and heated with district heating or exhaust air heat pump, or designed to the Swedish passive house criteria and heated with exhaust air heat pump. The findings show that the energy efficiency level of buildings and choice of heat supply system significantly influence the primary energy use and climate impacts of buildings as well as the lifecycle cost for the heating solutions. 
The energy balance calculations show that the passive heat pump heated building results in significantly lower final energy demand as well as purchased energy use compared to the BBR buildings heated with district heating or heat pump. The BBR heat pump heated building gives greater final energy and lower purchased energy use compared to the district heated alternative. In contrast to the district heated building, the purchased energy use and final energy demands are different for the heat pump heated buildings. Compared to the final energy demands, the purchased energy use are 63-66\% lower for the heat pump heated buildings.

This analysis demonstrates that primary energy use and climate impact of a building are largely determined by the energy supply system, as noted in previous studies e.g. Dodoo et al. [25], Gustavsson and Joelsson [26]. The results show that the choice of reference power plant and supply system have significant impact on the performance and ranking of the studied heating solutions for the buildings. Nevertheless the BBR heat pump heated building use the most primary energy and resulted in the most climate impact or least climate benefit compared to the other two alternatives, irrespective of the reference power plant.

For the baseline scenario assuming current typical conversion efficiencies for the supply systems, the BBR district heated building performs better than the passive heat pump heated buildings in terms of both primary energy and $\mathrm{CO}_{2}$ emissions when the reference electricity is produced from coal-fired plant. However, the passive heat pump heated building performs better than the BBR district heated building from primary energy perspective when electricity is produced from a reference fossil-gas fired plant. Still, the district heated building gives the lowest net fossil $\mathrm{CO}_{2}$ emissions for the reference fossilgas fired plant. Thus for both coal-fired and fossil-gas fired reference power plants, the BBR building with district heating solution gives the lowest net fossil $\mathrm{CO}_{2}$ emission followed by the passive house with heat pump solution.

For the plausible long-term scenario where energy supply is from a combination of improved fossil power plants and non-fossil power plants, the primary energy use and net fossil $\mathrm{CO}_{2}$ emissions for the heat pump heated buildings are improved significantly. The passive heat pump heated building gives the lowest net fossil $\mathrm{CO}_{2}$ emissions followed by the BBR district heated building while the BBR heat pump heated building gives the most fossil $\mathrm{CO}_{2}$ emissions, for both coal-fired and fossil-gas fired reference power plants. The primary energy use are about the same for the BBR district heated and passive heat pump heated buildings when the reference electricity is from coal-fired plant.

The district heating and heat pump heating systems analyzed in this study have different biomass needs and different approaches have been used to account for the implications of this in the study. The results suggest that the approach used to account for the spare biomass significantly influence the climate performance of heating solutions for buildings. Nevertheless this did not change the ranking of the heating solutions for the analyzed building versions.

The results of the lifecycle cost analysis indicate that heat pump solution with BBR level of building energy efficiency is the least economical among the studied alternatives while a passive house with heat pump solution is the most economical option. About 7-12\% lifecycle cost reduction is achieved when district heating is used instead of heat pump for a BBR code-compliant building. While the operation and maintenance costs are higher for the district heating solution, the investment cost for this solution is lower than that for the heat pump solutions. A lifecycle cost perspective is thus essential to fully account for these trade-off and all potential costs associated with the choice of a heating solution.

In a recent Swedish study on lifecycle cost analysis of heat supply options, Swing Gustafsson et al. [27] suggested that either district heating or heat pump may give the lowest overall cost for a detached house, depending on input parameter combinations and scenarios. This emphasizes the need to take local conditions into account when deciding on the choice of heat supply for buildings. Besides the explicit costs related to the choice of heating solution, heating solution for a new building may also affects the construction costs through other mechanisms e.g. building envelope design, ventilation solution used, and this should be considered in further studies.

The sensitivity of this study's results to uncertainties in various techno-economic parameters is demonstrated through considerations of different scenarios of real discount rates and annual energy price increase over the analysis period as well as different energy supply scenarios for both the present and the long terms. Notwithstanding, further studies need to be conducted to reduce the uncertainties linked to parameters as COP of the exhaust air heat pump and lifetimes of the analyzed heating solutions. The energy use and climate performances of the heating solutions for the buildings have been analyzed for the current climate conditions, based on dataset representative of the recent climate for the Swedish city of Växjö. Changing climate conditions may influence the performances of the solutions and this need to be considered in further studies. The latest climate change projection for Sweden suggests mean annual temperature increase of up to $5.5^{\circ} \mathrm{C}$ by 2100 , compared to the historical climate normal [28]. This will lead to significant reduction of space heating demands for Swedish buildings, as noted by Dodoo and Gustavsson [29].

In summary, this study indicates that the use of exhaust air heat pump in a BBR code-complaint house increases primary energy use and climate impacts compared to the use of cogenerated district heating in a similar house. The findings corroborate the growing body of literature that co-generated district heating is a primary energy efficient, climate-effective and costeffective means of supplying heat for buildings $[17,25$, 30]. The analysis presented here shows the importance of lifecycle and system-wide perspectives in analyzing the resource efficiency and climate impacts as well as the economic viabilities of heating solutions for houses. 


\section{References}

1. Tommerup, H., Rose, J. and Svendsen, S., (2007). Energy-efficient houses built according to the energy performance requirements introduced in Denmark in 2006, Energy and Buildings, 39 (10): 1123-1130.

2. Swedish Energy Agency (2013). Energy in Sweden 2012, Sweden. Accessed at www.energimyndigheten.se.

3. EU Directive 2018/844, EU Directive 2018/844 of the European Parliament and of the Council of 30 May 2018 amending Directive 2010/31/EU on the energy performance of buildings and Directive 2012/27/EU on energy efficiency. PE/4/2018/REV/1, OJ L 156.

4. Swedish Government Bill 2005/06:145, Swedish Government Bill 2005/06:145 National Programme for Energy Efficiency and Energy-smart Construction. Accessed at http://www.government.se on 12/04/2017.

5. Växjö Municipality, 2016. Energy plan for Växjö Municipality. Accessed on 30th January, 2019 at https://vaxjo.se

6. Swedish Competition Authority. 2015. The Swedish Competition Authority appeals district heating judgment. Accessed on 30th January, 2019 at www.konkurrensverket.se/globalassets/konkurrens/f aktablad/13 0380 faktablad vaxjokommun.pdf

7. Boverkets Författningssamling (Building and Planning Regulations). The National Board of Housing, Building and planning, Karlskrona, Sweden.

8. FEBY (Sveriges Centrum för Nollenergihus). 2012. Specification for zero energy, passive and lowenergy houses (in Swedish).

9. Gustavsson, L. and Karlsson, Å., 2002. A system perspective on the heating of detached houses. Energy Policy, 30(7): 553-574.

10. Gustavsson, L. and Karlsson, A. 2006. CO2 mitigation: On methods and parameters for comparison of fossil-fuel and biofuel systems. Mitigation and Adaptation Strategies for Global Change, 11(5-6): 935-959.

11. Strusoft. 2010. Overview of VIP-Energy. Available at https://strusoft.com/products/vip-energy

12. SVEBY, Brukarindata bostader version 1.1. (In English: User input data for dwellings). Accessed at http://www.sveby.org/hur-anvander-jagsveby/berakning/29th June, 2018. 2013.

13. Dodoo, A., Tettey, U.Y.A., Gustavsson, L. (2017). On input parameters, methods and assumptions for energy balance and retrofit analyses for residential buildings. Energy and Buildings. 137. 76-89.

14. Karlsson, Å. 2003. ENSYST, Version. 1.2. Lund: Lund University, Sweden.

15. E-mail communication with VEAB, 2014.
16. Gustavsson, L., Dodoo, A., Truong, N.L., Danielski, I. 2011. Primary energy implications of end-use energy efficiency measures in district heated buildings. Energy and Buildings. 43. 38-48.

17. Joelsson, A. 2008. Primary energy efficiency and $\mathrm{CO}_{2}$ mitigation in residential buildings. Doctoral thesis. Engineering and sustainable development, Mid Sweden University. Östersund, Sweden.

18. Joelsson, J. M., and Gustavsson, L. (2010). Reduction of $\mathrm{CO}_{2}$ emission and oil dependency with biomass-based polygeneration. Biomass and Bioenergy, 34(7), 967-984.

19. Truong, N.L., Dodoo, A., Gustavsson, L. (2018). Effects of energy efficiency measures in districtheated buildings on energy supply. Energy. 142. 1114-1127.

20. Harvey, D. (2010). Energy and the new reality 1: Energy efficiency and the demand for energy services. Routledge.

21. Vattenfall (2019). Fjärrvärmepriser och anslutningskostnad. (In English: District heating prices and connection cost). Available at https://www.vattenfall.se/fjarrvarme/priser/

22. NIBE, 2019. NIBE F750. Web available from https://www.nibe.eu

23. Danish Energy Agency (2016). Technology data for individual heating installation, Accessed on 31st January, 2019 https://ens.dk/en

24. Dodoo, A., Gustavsson, L., Tettey, U.Y.A. (2018) Cost-optimized energy-efficient building envelope measures for a multi-storey residential building in a cold climate. ICAE2018 22-25 August 2018, Hong Kong, China.

25. Dodoo, A., Gustavsson, L., and Sathre, R. (2010). Life cycle primary energy implication of retrofitting a wood-framed apartment building to passive house standard. Resources, Conservation and Recycling, 54(12), 1152-1160.

26. Gustavsson, L., and Joelsson, A. (2010). Life cycle primary energy analysis of residential buildings. Energy and Buildings, 42(2), 210-220.

27. Swing Gustafsson, M., Myhren, J., and Dotzauer, E. (2018). Life cycle cost of heat supply to areas with detached houses - a comparison of district heating and heat pumps from an energy system perspective. Energies, 11(12), 3266.

28. Swedish Meteorological and Hydrological Institute, 2011. Rossby Centre regional atmospheric model, RCA4. Accessed at http://www.smhi.se/enon 27 February, 2015.

29. Dodoo, A., and Gustavsson, L. (2016). Energy use and overheating risk of Swedish multi-storey residential buildings under different climate scenarios. Energy, 97, 534-548.

30. Truong, N.L., A. Dodoo, and L. (2015). Gustavsson, Renewable-based heat supply of multi-apartment buildings with varied heat demands. Energy, 93, p. 1053-1062. 